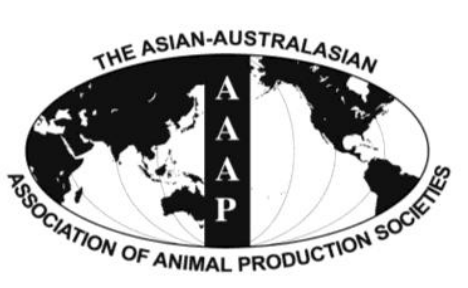

Open Access

Asian Australas. J. Anim. Sci.

Vol. 28, No. 6 : 903-910 June 2015

http://dx.doi.org/10.5713/ajas.14.0385

www.ajas.info

pISSN 1011-2367 elSSN 1976-5517

\title{
Modelling Pasture-based Automatic Milking System Herds: System Fitness of Grazeable Home-grown Forages, Land Areas and Walking Distances
}

\author{
M. R. Islam*, S. C. Garcia, C. E. F. Clark, and K. L. Kerrisk \\ Dairy Science Group, Faculty of Veterinary Science, The University of Sydney, Camden, NSW 2570, Australia
}

\begin{abstract}
To maintain a predominantly pasture-based system, the large herd milked by automatic milking rotary would be required to walk significant distances. Walking distances of greater than 1-km are associated with an increased incidence of undesirably long milking intervals and reduced milk yield. Complementary forages can be incorporated into pasture-based systems to lift total home grown feed in a given area, thus potentially 'concentrating' feed closer to the dairy. The aim of this modelling study was to investigate the total land area required and associated walking distance for large automatic milking system (AMS) herds when incorporating complementary forage rotations (CFR) into the system. Thirty-six scenarios consisting of 3 AMS herds (400, 600, 800 cows), 2 levels of pasture utilisation (current AMS utilisation of $15.0 \mathrm{t}$ dry matter [DM]/ha, termed as moderate; optimum pasture utilisation of $19.7 \mathrm{t}$ $\mathrm{DM} / \mathrm{ha}$, termed as high) and 6 rates of replacement of each of these pastures by grazeable CFR (0\%, 10\%, 20\%, 30\%, 40\%, 50\%) were investigated. Results showed that AMS cows were required to walk greater than 1-km when the farm area was greater than 86 ha. Insufficient pasture could be produced within a $1 \mathrm{~km}$ distance (i.e. 86 ha land) with home-grown feed (HGF) providing $43 \%, 29 \%$, and $22 \%$ of the metabolisable energy (ME) required by 400, 600, and 800 cows, respectively from pastures. Introduction of pasture (moderate): CFR in AMS at a ratio of 80:20 can feed a 400 cow AMS herd, and can supply $42 \%$ and $31 \%$ of the ME requirements for 600 and 800 cows, respectively with pasture (moderate): CFR at 50:50 levels. In contrast to moderate pasture, 400 cows can be managed on high pasture utilisation (provided $57 \%$ of the total ME requirements). However, similar to the scenarios conducted with moderate pasture, there was insufficient feed produced within 1-km distance of the dairy for 600 or 800 cows. An 800 cow herd required 140 and 130 ha on moderate and high pasture-based AMS system, respectively with the introduction of pasture: CFR at a ratio of 50:50. Given the impact of increasing land area past 86 ha on walking distance, cow numbers could be increased by purchasing feed from off the milking platform and/or using the land outside 1-km distance for conserved feed. However, this warrants further investigations into risk analyses of different management options including development of an innovative system to manage large herds in an AMS farming system. (Key Words: Automatic Milking System, Complementary Forage Rotations, Herd Size, Walking Distance, Grazeable HomeGrown Forages)
\end{abstract}

\section{INTRODUCTION}

Pasture-based dairy systems are based on the principle that $50 \%$ of the metabolisable energy (ME) requirement should be grazed from the pasture or home-grown forages (HGF; Garcia and Fulkerson, 2005). In an automatic milking system (AMS) with voluntary cow traffic,

\footnotetext{
* Corresponding Author: M. R. Islam. Tel: +61-2-9036-7750, Fax: +61-2-4655 2374, E-mail: md.islam@sydney.edu.au Submitted May 21, 2014; Revised Aug. 5, 2014; Accepted Oct. 25, 2014
}

increasing walking distances (from dairy to pasture) beyond $800 \mathrm{~m}$ is associated with an increased incidence of undesirably long milking intervals and reduction in milk yield (Islam et al., 2013; Lyons et al., 2014). Several potential strategies may be implemented in order to maintain walking distances less than 1-km in AMS farms. These are: i) maximising pasture yield to the highest potential; ii) increasing the dry matter (DM) grown per ha through the use of alternative grazeable forages such as incorporation of a complementary forage rotation (CFR); and iii) supplement cows using purchased feed or feed 
conserved greater than $1-\mathrm{km}$ from the dairy.

There is a potential to maximise pasture harvested by dairy cows up to approximately three-times the moderate commercial farm average $\sim 7 \mathrm{t}$ DM/ha (Garcia and Fulkerson, 2005; Beca, 2008) to $20 \mathrm{t} \mathrm{DM/ha.} \mathrm{Work}$ conducted over several years at two sites in Camden (NSW, Australia) showed that a rotation of kikuyu (Pennisetum clandestinum Hochst. Ex Chiov) in summer over-sown with a short-rotation ryegrass (Lolium multiflorum Lam.) in autumn yielded from 17.3 t DM/ha (Garcia et al., 2008) to 19.7 t DM/ha (Fariña et al., 2011a) under non-limiting nitrogen $(\mathrm{N})$ fertiliser and irrigation water inputs. Growth rate of pastures in these studies ranged from 40 to $103 \mathrm{~kg}$ $\mathrm{DM} / \mathrm{ha} / \mathrm{d}$ over nine months, which provided $50 \%$ of the total DM intake (9.8 to $12.2 \mathrm{~kg} \mathrm{DM} /$ cow/d) of cows from pasture alone throughout the months of September to March (Fariña et al., 2011a). Adoption and implementation of improved agronomic practices and pasture management in AMS could significantly increase pasture growth, reduce walking distances, improve cow traffic to the dairy and ultimately increase milk yield of cows in a pasture-based AMS.

Supply of $50 \%$ of the total DM from the pasture is an essential criterion to be considered as a pasture-based (Garcia and Fulkerson, 2005) AMS system. However, adoption of this pasture system alone may not be able to supply $50 \%$ of the total DM or ME requirement for a large AMS herd throughout the year. Further increases in pasture yield past $20 \mathrm{t} \mathrm{DM} / \mathrm{ha}$ will be difficult to achieve as this yield is believed to be near the ceiling yield of utilised pasture due to the seasonality of pasture growth (Rawnsley et al., 2007; Thorrold and Doyle, 2007). Increasing HGF yield per ha past this level rely upon alternative grazeable forage crops. This concept was behind the introduction of the CFR (Garcia et al., 2008; Islam and Garcia, 2012a) which supplied large volumes of grazeable CFR to AMS (Islam et al., 2012). Fariña et al. (2011a) reported the development of a complementary forage system (CFS) by combining an area with $65 \%$ pasture (kikuyu-ryegrass) and $35 \%$ CFR (grazeable plus conserved feed) and reported an estimated total of $\sim 28,000 \mathrm{~L}$ milk yield/ha/yr from HGF. Islam et al. (2012) in a modelling study reported the potential to incorporate CFR to achieve $28 \mathrm{t} \mathrm{DM} / \mathrm{ha} / \mathrm{yr}$ grazeable CFR for AMS cows. Therefore, introduction of CFR based grazeable HGF may create the potential to reduce walking distances and could improve farm profitability significantly as HGF are typically produced at lower cost per $\mathrm{kg}$ DM compared to purchased feeds (Chapman et al., 2008a, b).

Recent developments in AMS technology with respect to the robotic rotary (automatic milking rotary [AMR], DeLaval AMR, Tumba, Sweden) are expected to have the capacity to milk up to 800 cows (Kolbach et al., 2012). To achieve this cow number whilst maintaining greater than $50 \%$ of HGF within $1-\mathrm{km}$ distance of the dairy may be challenging. However, there is no information on the amount of pasture or CFS that could be supplied for a large AMS herd from within 1-km distance of the dairy. Such information is essential to develop management guidelines for a sustainable pasture-based large herds AMS farming system.

The objective of this modelling study was to investigate the ability to supply greater than $50 \%$ of HGF within $1-\mathrm{km}$ distance of the dairy for large AMS herds at Camden.

\section{MATERIALS AND METHODS}

\section{Scenarios and criterias}

Thirty-six scenario analyses were carried out to investigate grazeable areas required for different herd sizes in pasture alone or CFS based AMS systems (Table 1). A simple desktop model in MS Excel spreadsheet (Microsoft Office Excel, 2007) was used to analyse all 36 scenarios including farm areas required for different herd sizes and walking distances for the variety of herd and farm sizes.

Scenarios included three herd sizes (400, 600 and 800 cows) managed in two pasture utilisation systems. These two pasture utilisation are moderate AMS pasture yield of $15.0 \mathrm{t} \mathrm{DM} / \mathrm{ha} / \mathrm{yr}$ (termed as moderate) and a maximum utilised yield of $19.7 \mathrm{t} \mathrm{DM} / \mathrm{ha} / \mathrm{yr}$ (termed as high; Fariña et al., 2011a) (Table 2). Each of these herd sizes and pasture utilisation was incorporated with six levels of grazeable CFR $(0 \%, 10 \%, 20 \%, 30 \%, 40 \%$, and $50 \%$ of replacement of pasture by grazeable CFR) (Table 2).

Both moderate and high pasture systems in this study include kikuyu-ryegrass (short rotation) where ryegrass was over-sown in kikuyu in autumn. These pasture systems were managed in Camden, NSW but at two different sites. The moderate pasture was managed in Elizabeth Macarthur Agricultural Institute, Menangle at AMS research farm, whereas the high pasture was managed in the University of Sydney dairy farm, Corstorphine. Distances between the sites were $\sim 20 \mathrm{~km}$. Soil type, weather and site description of Menangle site where moderate pasture was grown have been reported by Garcia et al. (2008). These descriptions of Corstorphine site where high pasture was grown have been reported by Fariña et al. (2011a). The main difference between moderate and high pasture utilisation treatments was that the high pasture was managed under non-limiting nitrogen (N) fertiliser and irrigation water (Fariña et al., 2011a), but $\mathrm{N}$ and irrigation were limited at times in the moderate pasture system. Total and seasonal growth of kikuyu-ryegrass pastures can be found elsewhere (Garcia et al., 2008; Fariña et al., 2011a).

The grazeable CFR consisted of a rotation of maize (Zea mays L.) in spring-summer followed by forage rape 
Table 1. Scenarios of herd size and complementary forage system analysed in the study

\begin{tabular}{|c|c|c|}
\hline \multirow[t]{2}{*}{ Herd size (no.) } & \multicolumn{2}{|c|}{$\begin{array}{l}\text { Complementary forage system } \\
\text { (pasture plus CFR) }\end{array}$} \\
\hline & Pasture & CFR (\%) \\
\hline \multirow[t]{12}{*}{400} & Moderate AMS & 0 \\
\hline & $(15$ t DM/ha) & 10 \\
\hline & & 20 \\
\hline & & 30 \\
\hline & & 40 \\
\hline & & 50 \\
\hline & High & 0 \\
\hline & (19.7 t DM/ha) & 10 \\
\hline & & 20 \\
\hline & & 30 \\
\hline & & 40 \\
\hline & & 50 \\
\hline \multirow[t]{12}{*}{600} & Moderate AMS & 0 \\
\hline & $(15$ t DM/ha) & 10 \\
\hline & & 20 \\
\hline & & 30 \\
\hline & & 40 \\
\hline & & 50 \\
\hline & High & 0 \\
\hline & $(19.7$ t DM/ha) & 10 \\
\hline & & 20 \\
\hline & & 30 \\
\hline & & 40 \\
\hline & & 50 \\
\hline \multirow[t]{12}{*}{800} & Moderate AMS & 0 \\
\hline & (15 t DM/ha) & 10 \\
\hline & & 20 \\
\hline & & 30 \\
\hline & & 40 \\
\hline & & 50 \\
\hline & High & 0 \\
\hline & (19.7 t DM/ha) & 10 \\
\hline & & 20 \\
\hline & & 30 \\
\hline & & 40 \\
\hline & & 50 \\
\hline
\end{tabular}

AMS, automatic milking system; DM, dry matter.

(Brassica napus L.) in autumn-winter over-sown with shortrotation ryegrass in mid-autumn after first simulated grazing of forage rape, which had a combined annual forage production potential of $28 \mathrm{t} \mathrm{DM/ha/yr} \mathrm{(Islam} \mathrm{et} \mathrm{al.,} \mathrm{2012).}$ The forage production level was obtained using a modelling simulation of soil and long term climate (111 years) of Camden (Islam et al., 2012).

Calculating metabolisable energy requirement from pastures and complementary forage system for different herd sizes

As ME was the limiting factor (provided 9.0 to $12.2 \mathrm{MJ}$
Table 2. Pasture and forage yield used in the model and calculated potential metabolisable energy (ME) yield (MJ/ha) from home-grown pastures and complementary forage rotation (CFR)

\begin{tabular}{lcc}
\hline Pasture or CFR & $\begin{array}{c}\text { Yield } \\
\text { (t DM/ha/yr) }\end{array}$ & $\begin{array}{c}\text { ME yield }^{\mathrm{a}} \\
(\mathrm{MJ} / \mathrm{ha} / \mathrm{yr})\end{array}$ \\
\hline Moderate AMS pasture & $15.0^{\mathrm{b}}$ & 154,500 \\
High pasture & $19.7^{\mathrm{c}}$ & 202,910 \\
CFR & $28.2^{\mathrm{d}}$ & 290,460 \\
\hline
\end{tabular}

AMS, automatic milking system; DM, dry matter; HGF, home-grown feed.

${ }^{\mathrm{a}}$ Based on 10.3 MJ ME/kg DM for all HGF.

${ }^{\mathrm{b}}$ AMS base data. ${ }^{\mathrm{c}}$ Fariña et al., 2011. ${ }^{\mathrm{d}}$ Islam et al., 2012.

$\mathrm{ME} / \mathrm{kg}$ DM CFS) for the grazing lactating cows in the CFS system (Fariña et al., 2011a), herd requirements were calculated based on $\mathrm{ME}$ for all scenarios studied. Metabolisable energy content of pastures and double-crop CFR used in this study was 10.3 and $10.35 \mathrm{MJ} / \mathrm{kg} \mathrm{DM}$, respectively (Fariña et al., 2011a). Milk yield per cow was assumed to be $25 \mathrm{~L} / \mathrm{d}$ in calculating ME requirement of cows. This milk yield was based on moderate $300 \mathrm{~d}$ average yield of 7,500 L/cow in AMS research farm at Camden. Average live weight of a lactating cow was $600 \mathrm{~kg}$ (Fariña et al., 2011a).

Metabolisable energy requirement for maintenance for grazing cows was calculated using $0.56 \mathrm{MJ} \mathrm{ME} / \mathrm{kg} \mathrm{W}^{0.75}$ (range 0.53 to $0.58 \mathrm{MJ} \mathrm{ME} / \mathrm{kg} \mathrm{W}^{0.75}$ ) per cow (Nicol and Brookes, 2007). Metabolisable energy requirement for lactation was estimated to be 5.7 MJ ME/L milk (Nicol and Brookes, 2007), which was based on $3.8 \%$ milk fat and $3.1 \%$ protein of cows in AMS research farm at Camden. Total ME requirement for maintenance and lactation was therefore 210.4 MJ ME/cow/d.

Metabolisable energy yield (MJ/ha) of forages was calculated from DM yield of pastures (moderate, $15 \mathrm{t}$ $\mathrm{DM} / \mathrm{ha}$; or high, $19.7 \mathrm{t} \mathrm{DM} / \mathrm{ha})$, CFR (28.2 t DM/ha) and ME content (10.3 or $10.35 \mathrm{MJ} / \mathrm{kg} \mathrm{DM}$ ) of pastures and CFR, respectively (Table 2).

Farm areas (ha) required for different herd sizes and proportions of pasture or complementary forage system

In order to estimate farm areas (ha) required to supply $50 \%$ of the total ME requirement for all three herd sizes managed in a pasture (moderate or high) or CFS system, the amount of pasture supplied by a particular farm size scenario was calculated starting from 50 to 300 ha based on the yield of a particular pasture or CFS system. The supply for HGF per year (supply) was calculated by multiplying a particular farm size (ha) with ME yield (MJ/ha/yr) from a particular system.

Metabolisable energy requirement per year (demand) for a particular herd size was calculated by multiplying the total ME requirement of a cow (i.e. $210.4 \mathrm{MJ} / \mathrm{d}$ ) with $365 \mathrm{~d}$ 


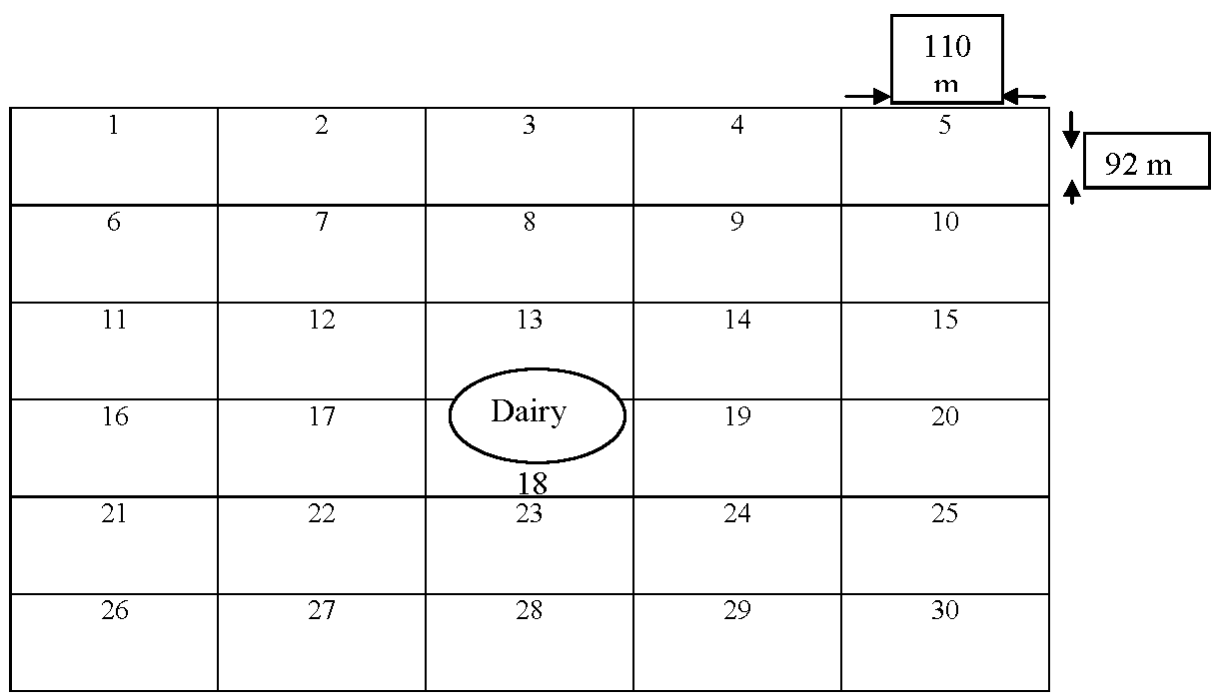

Figure 1. An example of 30 paddocks, each 1-ha farm structure for automatic milking system herds.

and then further multiplying this by the herd size. The product was divided by 2 in order to calculate $50 \%$ supply of the total ME requirement from pasture or HGF (as a pasture-based system is defined as a system in which $50 \%$ of the total diet is provided through pasture).

Supply was divided by the demand for a particular grazing system in order to identify the farm sizes (ha) that were able to supply $100 \%$ pasture requirement (or $50 \%$ of the total ME supply) for a particular herd. The same procedure was followed to calculate the farm size required for a CFS system that replaced pasture at $10 \%, 20 \%, 30 \%$, $40 \%$, and $50 \%$ level using grazeable CFR. Farm areas required to supply ME from moderate and high pasturebased forage production system are given in Supplementary Table S1 and S2, respectively.

\section{Walking distances from the dairy to pasture/forage for different farm areas}

In order to calculate the distance a cow travels for a particular farm area (ha), an AMS farm irrespective of areas or sizes was divided into 30 equally sized paddocks (Figure 1). In this system each paddock may be grazed in a day or 2 depending on the availability of pasture/forages in a particular season to represent a 30 and $60 \mathrm{~d}$ rotation respectively, typical for commercial Australian dairy farms. In this farm design, the dairy (milking parlour) was located at the centre of the AMS in order to keep distances equal from the dairy to all corners of the farm.

The 30 paddocks were divided horizontally into 5 and vertically into 6 blocks (Figure 1). For calculations, each paddock was initially considered as 1-ha, and the proportional value was use to extrapolate the distances to each different form scale. The dimension of a 1-ha paddock in this farm design was $110 \mathrm{~m} \times 92 \mathrm{~m}$ (Figure 1). The minimum walking distance was considered as $50 \mathrm{~m}$, in paddocks which were located closest to the dairy (paddocks 13 and 18; Figure 1).

Walking distances $(\mathrm{m})$ required for cows to reach the nearest point of the 30 paddocks was measured from the centre of the dairy. In all cases, the shortest possible distances required to reach a paddock from the dairy was always considered. Distance walked relative to area $(\mathrm{m} / \mathrm{ha})$ was calculated by dividing the distance (m) a cow walked to reach a paddock divided by 30 (i.e. 30 paddocks, 1-ha each). The number of paddocks located at each of the common distances from the dairy were also identified, and then converted to percentages so that the values could be used for any farm size (Table 3).

Table 3. Walking distance required by cows according to the location of the paddock in a 30 paddock automatic milking system herds

\begin{tabular}{lcccc}
\hline $\begin{array}{c}\text { Distance walk }(\mathrm{m}) \\
\text { in } 30 \text { paddocks }\end{array}$ & $\begin{array}{c}\text { Paddock identification } \\
\text { (in Figure 1) }\end{array}$ & No. of paddocks & \% paddock & Distance walk/ha (m) \\
\hline 50 & 13,18 & 2 & 7 & 2 \\
55 & $12,14,17,19$ & 4 & 13 & 2 \\
147 & $7,8,9,22,23,24$ & 6 & 20 & 5 \\
165 & $11,15,16,20$ & 4 & 13 & 6 \\
239 & $2,3,4,27,28,29$ & 6 & 20 & 8 \\
257 & $6,10,21,25$ & 4 & 13 & 12 \\
349 & $1,5,26,30$ & 4 & 13 & 12 \\
\hline
\end{tabular}


Based on the walking distances per ha of land (Table 3), distances a cow was required to walk to graze in a particular paddock was calculated by multiplying areas available and distance walked $(\mathrm{m})$ by a cow per ha (Supplementary Table S3). Accordingly, the walking distances for the various farm sizes were also calculated (Supplementary Table S4). An example of calculation of walking distance to paddock 1 from the dairy is given below:

i) Calculation of distance of a particular paddock (paddock 1) from the dairy

Distance of paddock 12 from the dairy $(110 \mathrm{~m} / 2), 55 \mathrm{~m}$

Distance of paddock 11 from paddock 12, $110 \mathrm{~m}$

Distance of paddock 1 from paddock 11 (92 m×2), $84 \mathrm{~m}$

Total distance, $349 \mathrm{~m}$

ii) No. of paddocks with similar distance paddocks to paddock 1 are paddocks $5,26,30=4$

iii) $\%$ paddocks in similar distances out of 30 paddocks $=(4 / 30) \times 100=13.3 \%$

iv) Walking distance walk $(\mathrm{m})$ per ha to the furthest corner out of 30 ha $=349 / 30=11.6 \mathrm{~m}$

v) Furthest distance walked $(\mathrm{km})$ in $100 \mathrm{ha}=100 \times 11.6$ $=1.16 \mathrm{~km}$.

\section{Home-grown feed availability from one-km area and additional feed requirements}

Metabolisable energy requirements and supply from 1$\mathrm{km}$ distance (i.e. $86 \mathrm{ha}$ ) of the dairy was calculated for all herd sizes (400, 600, and 800 cows) based on the calculation mentioned above. Additional ME required from other sources for different herd sizes were also calculated when herds are managed within 1-km distance of the dairy.

\section{Calculations and statistics}

A spreadsheet (Microsoft Office Excel, 2007) was used to calculate all data including farm areas required for different herd sizes and walking distances for the variety of herd and farm sizes.

\section{RESULTS}

Farm areas (ha) required for different herd sizes and proportions of pasture or complementary forage system

Moderate pasture utilisation AMS (15.0 t DM/ha) required 100, 150, and 200 ha land, respectively for 400, 600 , and 800 lactating cows herd when $50 \%$ of the total ME requirements are met from pastures (Table 4). The land area required decreased with the increase in replacement of pasture by CFR. Land area requirements were 70, 110, and 140 ha for 400,600 , and 800 cows herd, respectively with the replacement of $50 \%$ of pastures by CFR, the maximum proportion of CFR used in this study (Table 4).

High pasture utilisation AMS (19.7 t DM/ha) required 80,120 , and 160 ha land for 400, 600, and 800 lactating cow herd, respectively when $50 \%$ of the total requirements are met from pasture (Table 4). Land area requirements were 60,100 , and 130 ha for 400,600, and 800 cows herd, respectively with the replacement of $50 \%$ of pastures by CFR (Table 4).

\section{Walking distances associated with different farm areas}

Cows in AMS walk less than 1-km distance from the dairy for milking platforms up to 86 ha (Figure 2). The impact of increasing farm area on the proportion of paddocks between 1 and $2 \mathrm{~km}$ distance from the dairy and greater than $2 \mathrm{~km}$ is shown in Figure 2. The proportion of paddocks outside $1-\mathrm{km}$ distance from the dairy rapidly increased when areas increased past 86 ha. In this regard, only $20 \%$ of paddocks were within $1-\mathrm{km}$ when farm area

Table 4. Farm areas and stocking rate of cows required for different herd sizes managed in moderate and high pasture utilisation system with different rates of grazeable complementary forage rotation (CFR) in automatic milking system

\begin{tabular}{|c|c|c|c|c|c|c|c|c|}
\hline \multirow{3}{*}{ Pasture utilisation } & \multirow{3}{*}{ CFR $(\%)$} & \multirow{3}{*}{$\begin{array}{l}\text { Stocking rate } \\
(\text { cow/ha })\end{array}$} & \multicolumn{3}{|c|}{ Farm areas required (ha) } & \multicolumn{3}{|c|}{$\%$ home grown feed produced on farm ${ }^{1}$} \\
\hline & & & \multicolumn{3}{|c|}{ Herd size $(n)$} & \multicolumn{3}{|c|}{ Herd size $(n)$} \\
\hline & & & 400 & 600 & 800 & 400 & 600 & 800 \\
\hline \multirow{6}{*}{$\begin{array}{l}\text { Moderate } \\
(15.0 \mathrm{t} \mathrm{DM} / \mathrm{ha})\end{array}$} & 0 & 4.0 & 100 & 150 & 200 & 43 & 29 & 22 \\
\hline & 10 & 4.3 & 100 & 140 & 190 & 47 & 31 & 24 \\
\hline & 20 & 4.7 & 90 & 130 & 170 & 51 & 34 & 25 \\
\hline & 30 & 5.0 & 80 & 120 & 160 & 55 & 36 & 27 \\
\hline & 40 & 5.5 & 80 & 110 & 150 & 58 & 39 & 29 \\
\hline & 50 & 5.7 & 70 & 110 & 140 & 62 & 42 & 31 \\
\hline \multirow{6}{*}{$\begin{array}{l}\text { High } \\
\qquad(19.7 \text { t DM/ha) }\end{array}$} & 0 & 5.0 & 80 & 120 & 160 & 57 & 38 & 28 \\
\hline & 10 & 5.5 & 80 & 110 & 150 & 59 & 40 & 30 \\
\hline & 20 & 5.7 & 70 & 110 & 140 & 62 & 41 & 31 \\
\hline & 30 & 5.7 & 70 & 110 & 140 & 64 & 43 & 32 \\
\hline & 40 & 6.2 & 70 & 100 & 130 & 67 & 44 & 33 \\
\hline & 50 & 6.7 & 60 & 100 & 130 & 69 & 46 & 35 \\
\hline
\end{tabular}

DM, dry matter.

${ }^{1}$ Expressed in relation to metabolisable energy requirement of a herd. 


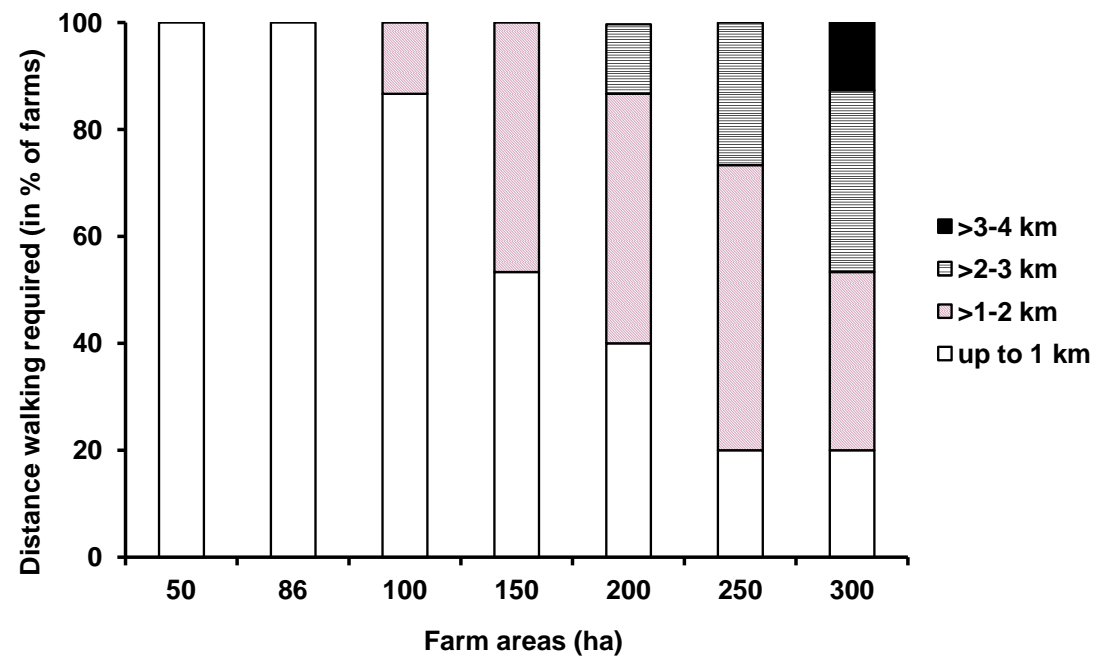

Figure 2. Walking distances $(\mathrm{km})$ required by cows for different farm areas (legends show distances in $\mathrm{km}$ ).

was increased to 300 ha.

Home-grown feed availability within one-km of the dairy and additional feed requirements

The moderate AMS pasture utilisation treatment modelled was unable to supply $50 \%$ of the total $\mathrm{ME}$ requirements from pasture for any of the studied herd sizes from within 1-km distance (i.e. 86 ha) of the dairy as it required 100 ha or more land for all herd sizes studied (Table 4). Only 43\%, 29\%, and $22 \%$ of the total ME requirements were able to be supplied by pasture for 400 , 600 , and 800 cows, respectively within $1-\mathrm{km}$ distance of the dairy (Table 4). Thus, calculated additional ME requirements were $47,753,83,831$, and $131,909 \mathrm{MJ} / \mathrm{d}$, respectively for 400, 600, and 800 cows herd (data not shown in Table).

The high pasture utilisation treatment modelled was able to supply $57 \%$ of the total ME requirement for 400 cows AMS herd from pasture (Table 4). However, it was only able to supply $38 \%$ and $28 \%$ of the total ME requirement from pasture for 600 and 800 cows respectively (Table 4). Thus, calculated additional total ME requirements were 78,425 and $120,503 \mathrm{MJ} / \mathrm{d}$ for 600 and 800 cows respectively (data not shown in Table). Metabolisable energy supply increased with the increase in proportion of grazeable CFR in both moderate and high pasture system.

\section{DISCUSSION}

It is acknowledged that the modelled layout presented in this study represents a 'perfect' layout and that few farms will be symmetrical, with equal sized paddocks and a dairy located in the centre of the farm. However, it is expected that the layout should provide a guideline for a 'best' farm design in order to minimise walking distances, maximise
HGF production and thus milk yield.

Farm areas (ha) required for different herd sizes and proportions of pasture or complementary forage system

Results presented showed that 400 and 800 cow herds require 100 and 200 ha land (stocking rate of 4 cows/ha) in order to provide $50 \%$ of the total ME requirement when moderate pasture utilisation were achieved. At similar stocking rates of $3.8 \mathrm{cows} / \mathrm{ha}$ and with $40 \%$ to $50 \%$ of diet provided as pasture, Fariña et al. (2013, 2011b) demonstrated production levels of $>30,000 \mathrm{~kg}$ milk/ha/yr in a conventional milking system (i.e. non-AMS). These authors concluded that the increase in milk production per ha achieved through a higher stocking rate was more effective compared to increases in milk production achieved by increasing milk yield per cow in a system. Fariña et al. (2011b) achieved the above mentioned milk yields with $11 \mathrm{t}$ $\mathrm{DM} / \mathrm{ha}$ utilised pasture, which was lower compared to the utilised pasture $(15 \mathrm{t} \mathrm{DM} / \mathrm{ha})$ in the moderate system. Therefore, there is a good prospect of achieving a target milk yield of $\sim 7,500 \mathrm{~kg} \mathrm{milk/cow/lactation} \mathrm{or} \sim 30,000$ $\mathrm{kg} / \mathrm{ha}$ from AMS with moderate pasture utilisation in any herd scenarios from 400 to 800 lactating cows (i.e. 4 cows/ha). Our results also indicate a potential to further increase in stocking rates up to 5 cows/ha for all studied herd sizes under high pasture utilisation (19.7 t DM/ha; Fariña et al., 2011a). However, increased land area associated with the increase in herd size will impact walking distances and are therefore expected to impact negatively on milking frequency and milk production in AMS (Lyons et al., 2014).

Our results also indicated the potential to reduce land areas in AMS farming systems through the strategic replacement of pastures by CFR. Replacement of pasture by grazeable CFR on up to $50 \%$ of the grazing area indicated 
the potential to reduced the grazing area up to 50 and 30 ha under moderate and high pasture utilisation, respectively (depending on the size of AMS herd). Fariña et al. (2011a) showed that a pasture-based CFS system $(65 \%$ pasture and $35 \%$ CFR [grazeable plus conserved forages]) was able to provide $\sim 28,000 \mathrm{~L}$ milk/ha/yr ( 7,500 L/cow/lactation) with a stocking density of 4.7 cows/ha. Our result suggest that similar stocking density ( $\sim 5$ cows/ha) would be achievable in a 70:30 pasture (moderate):grazeable CFR and that even higher stocking rates ( 6.7 cows/ha) may be achievable with high levels of pasture and CFR utilisation. These results indicate the potential of incorporating a grazeable CFR into the farm system in achieving a target $(25,000$ to 28,000 L/ha/yr) milk yield in AMS farming system. In addition to potentials of increasing milk yield, there may be other advantages of grazeable CFS in AMS system. Firstly, it may reduce the land required by a large herd such as 800 cows AMS farm. Secondly, it may also increase milk yield by reducing the walking distances of cows (Lyons et al., 2014).

However, the greatest impact of introducing grazeable CFS in the large herd AMS farming system can occur by increasing the consumption of HGF, which could significantly improve farm profitability. Chapman et al. (2008a, b) reported that pasture (or HGF) can usually be supplied at lower cost per kg DM compared to purchased feed or concentrates. Nonetheless, it is important to mention that HGF such as forage rape or maize are not widely used for grazing in the industry. This is likely to be largely attributed to the combination of lack of understanding of their potential impacts on farm financial performance and because the risks associated with their use have not been quantified. Several authors have reported that one of the major factors limiting the adoption of new technologies is the perception of risk (Marra et al., 2003; Hardaker et al., 2004; Ghadim et al., 2005). However, Fariña et al. (2013) reported lower financial risks associated with CFS $(65 \%$ pasture and $35 \% \mathrm{CFR}$ ) due to the higher degree of diversification of forage base in the system compared to pasture alone. Similarly, Chapman et al. (2008b) also reported lower financial risks created through the integration of different forage crops with perennial pastures compared to $100 \%$ perennial ryegrass in dryland farms. Nonetheless, further studies on management and financial risks of growing HGF are required in order to build industry confidence regarding the use of grazeable HGF in AMS farming system.

\section{Walking distances associated with variable farm size}

Our results revealed that AMS cows should be grazed or managed within 86-ha farm areas if walking distances (distance between dairy and paddock) are to be capped at 1$\mathrm{km}$. However, even the smallest herd used in our study (i.e.
400 cows) required 100 ha land and was associated with $13 \%$ of paddocks having distances from the dairy which exceeded 1-km. A largest herd simulated (800 cows) had $60 \%$ of paddocks located more than $1-\mathrm{km}$ from the dairy with moderate pasture utilisation. Overall, our results showed that neither pasture nor CFS would allow large AMS herds (600 or 800 cows) to be grazed within $1-\mathrm{km}$ distance of the dairy if $50 \%$ of the diet was to be generated through grazeable feed although increased proportion of CFS decreased land area requirements and hence maximum and average walking distances. These findings indicate that alternative approaches may be required for the management of larger AMS grazing herds.

Several alternative options could be considered for large AMS herds. First, HGF may be grown for silages and/or cut and carry $1-\mathrm{km}$ past the dairy and could be offered in a dedicated feeding area or feed pad or in the paddock located within 1-km of the dairy. Second, increasing the amount of purchased feed beyond the simulated $50 \%$ presented in the current study may allow the intensification of the farm system to minimise the need to graze paddocks more than $1-\mathrm{km}$ from the dairy. Third, cows could be allowed to walk longer distances for grazing with penalties arising either through reduced milk yields or increased labour required to encourage cow traffic. However, it should be kept in mind that implementation of these proposed options in AMS farms may be challenging and there may be unforseen impacts of these options.

\section{CONCLUSION}

This study provided an understanding of the land areas required by different herd sizes and the associated walking distances to graze that area in a pasture-based AMS farming system. The results showed that AMS cows should be managed within 86 ha if the proportion of paddocks located more than $1-\mathrm{km}$ from the dairy are to be minimised. Moderate pasture utilisation (15 t DM/ha) cannot supply $50 \%$ of the ME requirements for any AMS herd $\geq 400$ cows with the modelled farm sizes. However moderate pasture: CFR at a ratio of 80:20 and high pasture utilisation (19.7 t $\mathrm{DM} / \mathrm{ha}$ ) alone supplied $50 \%$ of the ME requirements for 400 AMS cows within 1-km of the dairy. An AMS herd $\geq 600$ cows cannot be managed within 86 ha either in pasture (moderate or high) or CFS system without provision of an additional external feed source. Therefore, either purchased or conserved feed should be supplied, or cows should be allowed to walk longer distances for pasture in order to maintain large AMS herds. Further work should be conducted on financial and management risks in order to maintain large AMS herds within 1-km distance of the dairy. 


\section{ACKNOWLEDGMENTS}

The authors thank the Dairy Research Foundation for its support of the Dairy Science Group and the investors of the FutureDairy project (Dairy Australia, NSW Department of Primary Industries, The University of Sydney, and DeLaval).

\section{REFERENCES}

Beca, D. A. 2008. Tri-nations revisited: Profitability variations between the average and the best in South Africa, Australia and New Zealand. Red Sky Agricultural, Warrnambool, Victoria, Australia.

Chapman, D. F., S. N. Kenny, D. Beca, and I. R. Johnson. 2008a. Pasture and forage crop systems for non-irrigated dairy farms in southern Australia. 1. Physical production and economic performance. Agric. Syst. 97:108-125.

Chapman, D. F., S. N. Kenny, D. Beca, and I. R. Johnson. 2008 b. Pasture and forage crop systems for non-irrigated dairy farms in southern Australia. 2. Inter-annual variation in forage supply, and business risk. Agric. Syst. 97:126-138.

Fariña, S. R., S. C. Garcia, and W. J. Fulkerson. 2011a. A complementary forage system whole-farm study: forage utilisation and milk production. Anim. Prod. Sci. 51:460-470.

Fariña, S. R., S. C. Garcia, W. J. Fulkerson, and I. M. Barchia. 2011b. Pasture-based dairy farm systems increasing milk production through stocking rate or milk yield per cow: pasture and animal responses. Grass Forage Sci. 66:316-332.

Fariña, S. R., A. Alford, S. C. Garcia, and W. J. Fulkerson. 2013. An integrated assessment of business risk for pasture-based dairy farm systems intensification. Agric. Syst. 115:10-20.

Garcia, S. C. and W. J. Fulkerson. 2005. Opportunities for future Australian dairy systems: A review. Aust. J. Exp. Agric. 45:1041-1055.

Garcia, S. C., W. J. Fulkerson, and S. U. Brookes .2008. Dry matter production, nutritive value and efficiency of nutrient utilization of a complementary forage rotation compared to a grass pasture system. Grass Forage Sci. 63:284-300.

Ghadim, A. K. A., D. J. Pannell, and M. P. Burton. 2005. Risk, uncertainty, and learning in adoption of a crop innovation. Agric. Econ. 33:1-9.

Hardaker, J. B., J. W. Richardson, G. Lien, and K. D. Schumann. 2004. Stochastic efficiency analysis with risk aversion bounds: A simplified approach. Aust. J. Agric. Resour. Econ. 48:253270
Islam, M. R. and S. C. Garcia. 2012. Effects of sowing date and nitrogen fertilizer on forage yield, nitrogen- and water-use efficiency and nutritive value of an annual triple-crop complementary forage rotation. Grass Forage Sci. 67:96-110.

Islam, M. R., S. C. Garcia, and K. Kerrisk. 2012. A modelling approach to screen grazeable forage options for automatic milking system herds. In: Proceedings of 5th Australasian Dairy Science Symposium 2012 (Eds. J. Jacobs, S. C. Garcia, S. Little, D. Barber, G. Edwards, J. Roche, J. Jago, and D. Pacheco). National Dairy Alliance, Melbourne, Australia. pp. 459-460.

Islam, M. R., C. E. F. Clark, K. Kerrisk, S. C. Garcia, and N. A. Lyons. 2013. Land areas required, associated walking distance and milking interval for large herds in pasture based automatic milking system. Proc. Precis. Dairy Conf., June 26-27, 2013; Rochester, MN, USA.

Kolbach, R., K. L. Kerrisk, S. C. Garcia, and N. K. Dhand. 2012. Attachment accuracy of a novel prototype robotic rotary and investigation of two management strategies for incomplete milked quarters. Comp. Electr. Agric. 88:120-124.

Lyons, N. A., K. L. Kerrisk, and S. C. Garcia. 2014. Milking frequency management in pasture-based automatic milking systems: A review. Livest. Sci. 159:102-116.

Marra, M., D. J. Pannell, and A. Abadi Ghadim. 2003. The economics of risk, uncertainty and learning in the adoption of new agricultural technologies: where are we on the learning curve? Agric. Syst. 75:215-234.

Nicol, A. M. and I. M. Brookes. 2007. The metabolisable energy requirements of grazing livestock. In 'Pasture and Supplements for Grazing Animals: Proceedings of the New Zealand Society of Animal Production 2007' (Eds P. V. Rattray, I. M. Brookes, and A. M. Nicol). Occasional Publication No. 14, New Zealand. pp. 151-172.

Rawnsley, R. P., D. J. Donaghy, and D. R. Stevens. 2007. What is limiting production and consumption of perennial ryegrass in temperate dairy regions of Australia and New Zealand? In: Proceedings of the Australasian Dairy Science Symposium 2007 (Eds. D. F. Chapman, D. A. Clark, K. L. Macmillan, D. P. Nation). National Dairy Alliance, Melbourne, Australia. pp. 256-274.

Thorrold, B. and P. T. Doyle. 2007. Nature or nurture - forces shaping the moderate and future state of dairy farming in New Zealand and Australia. In: Proceedings of the Australasian Dairy Science Symposium 2007 (Eds. D. F. Chapman, D. A. Clark, K. L. Macmillan, D. P. Nation). National Dairy Alliance, Melbourne, Australia. pp. 450-460. 